\title{
ROLUL VALORILOR ÎN EDUCAŢIE
}

Ioan Scheau*

Abstract: The Role of Values in Education. The present paper will analyze the matter of values in the Romanian educational system, in the context of the present changes in the society. The paper is composed of two parts:

- a theoretical one: that presents the relation between ethics and moral, ethics' areas of study (meta-ethics, normative ethics and applied ethics), the object and the principles of ethics.

- a practical one: that presents the results of a research that took place in March-April 2016, and which involved students from 1 Decembrie 1918 University of Alba Iulia and teachers from the pre university education, from Alba and Hunedoara counties. This research focused on the following aspects: the matter of values in education, their role in the foundation of the present educational ideal, as well as the combination of the Romanian and the European values in the development of the pupils.

Keywords: moral, ethics, values, education, educational ideal.

\section{Consideraţii teoretice}

$\mathrm{Cu}$ studiul teoriei valorilor se ocupă axiologia, un domeniu fundamental al filosofiei generale alături de ontologie şi gnoseologie, aceasta presupunând analiza conceptelor de bine şi rău, de corect şi incorect, precum şi identificarea unui set de valori capabil să regleze comportamentul uman în societate.

Se pun deci întrebările: ce sunt valorile ? Şi care este rolul lor în comportamentul uman ? Conform ,Dicţionarului de filozofie Larousse” valoarea reprezintă ,tot ceea ce este dezirabil (şi nu numai ceea ce este dorit). Există valori biologice (sănătate, putere fizică), economice (impozit), estetice (frumuseţe), morale (virtute), religioase (sacrul). Noţiunea de valoare (ceea ce trebuie să fie) se deosebeşte de aceea de adevăr (ceea ce este); este o noţiune practică, noţiune care nu are sens decât în raport cu experienţa voinţei sau a acţiunii.

* PhD, Assistant Professor, Faculty of Orthodox Theology at „1 December 1918” University, Alba Iulia, Romania. 
1. Ea implică un element dinamic, sub forma unei dorinţe sau a unei sensibilităţi din partea subiectului: un obiect sau o fiinţă ni se par a avea cu atât mai multă valoare cu cât dorinţa noastră este mai mare; invers, un obiect de mare valoare (aur, argint) poate să nu aibă nici o valoare în ochii noştri dacă nu dorim să-1 posedăm.

2. Valoarea are totuşi un aspect obiectiv sau static (caracterul social, tradiţional sau universal uman al valorii: de exemplu, al culturii, al onestităţii, al fidelităţii, etc.)"1.

$\mathrm{Cu}$ alte cuvinte, valoarea are o dublă polaritate: obiectivă deoarece se aplică unui obiect oarecare, acesta putând fi şi un proces social; şi subiectivă - deoarece presupune conştiinţa omului care valorizează acel obiect oarecare. Se pune atunci problema clasificării valorilor, deoarece astăzi există un sistem al valorilor care reglementează activitatea socială. Conform aceluiaşi „Dicţionar de filozofie" în general, se disting trei grupe de valori: adevăratul, binele şi frumosul ${ }^{2}$, care corespund unor domenii filosofice tradiţionale: cunoaşterea (gnoseologia), etica şi estetica. Dincolo de aceste domenii trebuie să distingem între: valori general umane, ce se aplică tuturor oamenilor pentru a deveni, aşa cum doreau vechii greci, nişte cetăţeni model, aici intrând: binele, adevărul, dreptatea; şi valori democratice, ce trebuie asigurate, conform celor spuse de John Locke, de către stat, aici intrând: drepturile omului dar şi libertatea sau toleranţa.

Marin Călin în lucrarea „Filosofia educaţiei” distinge următoarele categorii de valori:

a) valori vitale necesare apărării vieții şi mediului cum sunt sănătatea (fizică şi mentală), tonusul şi forţa fizicăa, frumuseţea şi armonia organismului, starea de echilibru a mediului, bunurile materiale şi prosperitatea economică, etc.;

b) valorile morale, politice, juridice şi istorice necesare existenţei unui stat şi naţiuni cum sunt democraţia, suveranitatea,

${ }^{1}$ Julia, Didier Dicționar de filozofie, București, Edit. Univers Enciclopedic, 1996, p. 354

${ }^{2}$ Ibidem, p. 354. 
binele, dreptatea, curajul, înţelepciunea, independenţa, legalitatea, demnitatea, iubirea de neam, etc.;

c) valori teoretice necesare cunoaşterii şi creației umane, cum sunt adevărul, evidenţa, obiectivitatea, imaginarul ştiinţific;

d) valori estetice si religioase, care privesc contemplarea lumii şi a creațiilor umane ${ }^{3}$.

Dincolo de această clasificare a valorilor trebuie spus că valoarea etică fundamentală este binele, deoarece societatea trebuie condusă în funcţie de binele general, aşa cum, la Platon, Ideea de Bine guvernează Lumea Ideilor dar, prin analogie, şi Lumea obiectelor şi fenomenelor, adică lumea aceasta în care noi trăim. De altfel, morala creştină, prin ideea de liber arbitru, acceptă distincţia dintre bine şi rău ca factor central ce coordonează activitatea umană, binele fiind lucrul de dorit în sine, râul fiind de lepădat. Această ideea guvernează şi astăzi etica socială.

„În religie, etică şi filozofie, dihotomia binele şi răul se referă la locaţia de pe un spectru liniar a unor obiecte, dorinţe sau comportamente, direcţia bună fiind pozitivă din punct de vedere moral, iar răul fiind direcţia negativă. Binele este un concept larg asociat de obicei cu viaţa, continuitatea, fericirea, iubirea, prosperitatea şi dreptatea. Răul este de obicei asociat cu fărădelegi conştiente şi deliberate, intenţia de a face rău altora, umilirea persoanelor, acte de violenţă inutilă şi fără discernământ"4.

\section{Cercetare privind rolul valorilor în educaţie}

Informaţii generale. Cercetarea de faţă s-a desfăşurat în perioada martie-aprilie 2016, la nivelul cadrelor didactice din învăţământul preuniversitar din județele Alba şi Hunedoara, precum şi în rândul

${ }^{3}$ Călin, Marin C. Filosofia educaţiei, Bucureşti, Edit. Aramis, 2001, p. 108109

${ }^{4}$ Pătroc, Dan Etică şi deontologie pedagogică, Blog personal, curs I, p. 2, consultat la http://socioumane.ro/blog/danpatroc/files/2013/01/CURSUL-1.pdf (accesat la data de 18.01.2016). 
studenţilor Universităţii „1 Decembrie 1918” din Alba Iulia. La cercetare au participat un număr de 53 de cadre didactice, atât din mediul urban cât şi din mediul rural, precum şi 53 de studenţi ai Universităţii „1 Decembrie 1918”. Ca şi metodă de cercetare a fost utilizată metoda chestionarului, acesta fiind aplicat persoanelor din grupul analizat.

Scopul, obiectivele şi ipotezele cercetării. Scopul cercetării a fost analiza problemei valorilor în cadrul sistemului românesc de învăţământ, în contextul actualelor schimbări din societate. Obiectivele cercetării sunt:

- să identifice rolul valorilor în cadrul sistemului de învăţământ românesc, inclusiv în concretizarea idealului educaţional,

- să identifice principalele valori, generale şi europene, considerate importante în cadrul şcolii,

- să coreleze analiza cantitativă şi calitativă a datelor pentru a surprinde rolul valorilor în educaţie.

Pentru desfăşurarea cercetării a fost formulată următoarea ipoteză: utilizarea valorilor, generale şi europene, în cadrul activităţii didactice, duce la o educaţie socială de calitate, utilă integrării sociale a absolvenţilor.

Metodologia cercetării. În concordanţă cu scopul şi obiectivele cercetării a fost aleasă metoda de cercetare, chestionarul. Acesta a fost aplicat persoanelor din cadrul grupului ţintă cu scopul identificării informaţiilor necesare confirmării sau infirmării ipotezei propuse.

Interpretarea datelor. Chestionaşi în legătură cu necesitatea unui ideal educaţional în cadrul sistemului de învăţământ românesc, cei mai mulţi repondenţi consideră utilă această abordare, dar - contrar aşteptărilor noastre, care am fi bănuit o unanimitate a repondenţilor există şi persoane care consideră că sistemul românesc de învăţământ nu are nevoie de un model de educaţie, situaţia fiind cu atât mai dificilă cu cât răspunsurile negative sunt mai dese în cazul profesorilor. Situaţ̧ia statistică arată astfel: 


\begin{tabular}{|l|c|c|}
\hline & Profesori învăţământ preuniversitar & Studenţi \\
\hline $\mathrm{Da}$ & $92,46 \%$ & $96,33 \%$ \\
\hline $\mathrm{Nu}$ & $7,54 \%$ & $3,77 \%$ \\
\hline
\end{tabular}

Răspunsurile negative la prima întrebare a chestionarului au fost justificate astfel: pentru profesori prin ideea că modelul poate deveni un patern impus de sistem, iar pentru studenţi prin încurajarea dezvoltării personale a individului bazată pe aptitudinile acestuia pentru formarea de atitudini.

Cei care au răspuns afirmativ au fost chestionaţi în legătură cu trăsăturile pe care acest model educaţional ar trebui să le posede, răspunsurile fiind foarte variate, de la încurajarea dezvoltării personalităţii elevului, până la formarea de competenţe necesare integrării pe piaţa muncii. Se pare că cele două direcţii trebuie să devină liniile generale ale educaţiei din România, adică şcoala trebuie să-i asigure elevului atât integrarea socială, inclusiv pe piaţa muncii, cât şi dezvoltarea personalităţii sale.

Al doilea item al chestionarului a cerut repondenţilor să precizeze dacă modelul educaţional ar trebui fundamentat pe valori. Dacă în cazul profesorilor am întâlnit unanimitatea, în cazul studenţilor să păstrează acel procent de $3,77 \%$ care susţin că idealul educaţional nu ar trebui fundamentat pe valori ci ar trebui fundamentat pe capacitatea fiecărui individ, oamenii fiind diferiţi, şi pe dezvoltarea spiritului inovativ, al curiozităţii elevilor prin capacităţi antreprenoriale.

Celor care au răspuns afirmativ li s-a cerut să precizeze care sunt valorile pe care idealul moral ar trebui să se bazeze, răspunsurile fiind evidenţiate în tabelul următor în funcţie de frecvenţa de apariţie:

\begin{tabular}{|c|c|}
\hline Profesori învăţământ preuniversitar & Studenţi \\
\hline $\begin{array}{ll}\text { - } & \text { adevărul } 49,05 \% \\
\text { - } & \text { dreptatea } 35,84 \% \\
\text { - } & \text { binele } 22,64 \%\end{array}$ & $\begin{array}{ll}\text { - } & \text { dreptatea } 56,60 \% \\
\text { - } & \text { adevărul } 47,16 \% \\
\text { - } & \text { binele } 45,28 \%\end{array}$ \\
\hline
\end{tabular}


- $\quad$ libertatea $20,74 \%$

- $\quad$ respect $16,98 \%$

- frumosul 15,09\%

- corectitudinea $11,32 \%$

- credinţa $11,32 \%$

- Sub $10 \%$ responsabilitatea, egalitatea, iubirea şi drepturile omului
- $\quad$ libertatea $26,41 \%$

- frumosul 13,20\%

- corectitudine $11,32 \%$

- răbdarea $11,32 \%$

- Sub 10\% apar: egalitatea, respectul, drepturile omului şi sinceritatea

Menţionăm faptul că există şi situaţii în care repondenţi nu au precizat anumite valori în sine, ci au precizat diferite categorii de valori pe care idealul educaţional ar trebui fundamentat, cum ar fi: valorile morale, valorile sociale, valorile estetice sau valorile patriotice.

Următorii doi itemi au cerut repondenţilor să clasifice valorile fundamentale şi europene în funcţie de importanţa şi rolul lor în formarea individului. Valorile fundamentale au fost: adevărul, binele, frumosul, dreptatea şi libertatea, iar cele europene au fost: respectarea demnităţii umane, respectarea democraţiei, respectarea egalităţii, respectarea statului de drept, respectarea drepturilor omului.

În prima situaţie, cea referitoare la valorile generale, situaţia centralizatoare se prezintă astfel:

\begin{tabular}{|l|c|c|}
\hline & $\begin{array}{c}\text { Profesori învăţământ } \\
\text { preuniversitar }\end{array}$ & Studenţi \\
\hline adevărul & $94(1)$ & $99(1)$ \\
\hline binele & $164(3)$ & $163(4)$ \\
\hline frumosul & $231(5)$ & $252(5)$ \\
\hline dreptatea & $124(2)$ & $121(2)$ \\
\hline libertatea & $168(4)$ & $160(3)$ \\
\hline
\end{tabular}


Se constată o similitudine a răspunsurilor, cu o mică inversare între bine şi libertate, profesorii considerând binele mai important decât libertatea în cadrul formării individului, tinerii afirmându-şi dorinţa de a avea mai multă libertate. În cazul profesorilor, corelaţia cu itemul anterior este evidentă, în cazul studenţilor această inversare este cu atât mai discutabilă cu cât la itemul anterior este prezentă o diferenţă de aproape douăzeci de procente între cele două valori inversate acum.

În a doua situaţie, cea referitoare la valorile europene, situaţia centralizatoare se prezintă astfel:

\begin{tabular}{|l|c|c|}
\hline & $\begin{array}{c}\text { Profesori învăţământ } \\
\text { preuniversitar }\end{array}$ & Studenţi \\
\hline $\begin{array}{l}\text { respectarea } \\
\text { demnităţii umane }\end{array}$ & $87(1)$ & $127(3)$ \\
\hline $\begin{array}{l}\text { respectarea } \\
\text { democraţiei }\end{array}$ & $201(5)$ & $230(5)$ \\
\hline $\begin{array}{l}\text { respectarea } \\
\text { egalităţii }\end{array}$ & $104(2)$ & $101(1)$ \\
\hline $\begin{array}{l}\text { respectarea } \\
\text { statului de drept }\end{array}$ & $183(4)$ & $223(4)$ \\
\hline $\begin{array}{l}\text { respectarea } \\
\text { drepturilor omului }\end{array}$ & $160(3)$ & $114(2)$ \\
\hline
\end{tabular}

Dacă în cazul valorilor tradiţionale se constată o similitudine între răspunsurile cadrelor didactice şi răspunsurile studenţilor, în cazul valorilor europene similitudinea există doar în cazul valorilor considerate neimportante cum ar fi: democraţia şi statul de drept. Aici poate fi tocmai o lipsă de educaţie democratică sau anumite reminiscenţe din regimul totalitar transmise şi noilor generaţii, şi anume că statul de drept nu contează, iar democraţia este o himeră. În ceea ce priveşte valorile europene importante preferinţele repondenţilor sunt foarte diferite: dacă profesorii consideră respectarea demnităţii umane ca fiind fundamentală, studenţii 
consideră egalitatea ca fiind cea mai importantă valoare, respectarea drepturilor omului completând podiumul în ambele cazuri.

Ultima întrebare a chestionarului a pus repondenţii în situaţia de a descrie idealul educaţional în condiţiile îmbinării valorilor tradiţionale cu valorile europene. Pentru cadrele didactice, cele mai importante aspecte evidenţiate sunt: respectarea multiculturalităţii, dezvoltarea armonioasă a personalităţii elevilor, valorificarea parteneriatelor şcoală - familie - comunitate, creşterea numărului de ore de cultură civică. Există şi voci care susţin că nu trebuie să impunem un anumit model ci să creăm cadrul de dezvoltare a elevilor pe valori prin diferite activităţi practice pe care aceştia să le desfăşoare. Pentru studenţi, cele mai importante aspecte evidenţiate sunt: cadrul didactic să devină model de urmat pentru elevii săi, explicarea tuturor valorilor în vederea înţelegerii lor corecte, colaborarea şcolii cu familia şi societatea în realizarea idealului educaţional, sarcina aceasta nefiind doar a şcolii. Ca şi profesorii, studenţi susţin că modelul nu trebuie impus, ci elevii trebuie îndrumaţi către el prin desfăşurarea de activităţi creative.

\section{Concluzii}

În urma analizei datelor considerăm că ipoteza propusă a fost validată, utilizarea valorilor, tradiţionale şi europene, în educaţie ducând la o educaţie socială de calitate, aceasta asigurând integrarea elevilor atât în societate cât şi pe piaţa muncii. Ne bucură faptul că Ministerul Educaţiei înţelege importanţa educaţiei sociale a elevilor, această disciplină fiind introdusă pentru studiu în noul plan cadru pentru gimnaziu aprobat în luna aprilie a acestui an, din păcate doar câte o oră pe săptămână pe parcursul întregului ciclu gimnazial.

\section{Bibliografie}

1. Călin, Marin C., Filosofia educaţiei, Bucureşti, Edit. Aramis, 2001.

2. Julia, Didier, Diç̧ionar de filozofie, Bucureşti, Edit. Univers Enciclopedic, 1996. 
3. Pătroc, Dan, Etică şi deontologie pedagogică, Blog personal, curs I, consultat la http://socioumane.ro/blog/danpatroc/files/2013/01/CURSUL-1.pdf (accesat la data de 18.01.2016).

4. Scheau, Ioan, Idealul moral, punct de plecare în concretizarea noului model educaţional, în „Educaţia din perspective valorilor”, t. II: Summa paedagogica, Alba Iulia, Edit. Aeternitas, 2010.

5. Scheau, Ioan, Idealul educaţional iluminist la Rousseau şi Kant, în V. Mândâcanu, I. Scheau, D. Opriş (eds.), „Educaţia umanistă în perspectiva triadei: Pedagogie - Filozofie - Teologie", Chişinău, Edit. Pontos, 2011.

6. Scheau, Ioan Problema valorilor în fundamentarea noului ideal educaţional, în D. Opriş, I. Scheau, V. Mândâcanu (eds.), „Educaţia din perspectiva valorilor. Studii, analize, sinteze", Chişinău, Edit. Pontos, 2012. 